\title{
MIGRATION LOSSES OF BOSNIA AND HERZEGOVINA AND DEMOGRAPHIC AGING
}

\author{
Stevo Pasalic ${ }^{1 *}$ and Darko Pasalic ${ }^{2}$ \\ ${ }^{1}$ Prof. Dr., University of East Sarajevo, Bosnia and Herzegovina, stevo.pasalic@gmail.com \\ ${ }^{2}$ Prof. Dr., University NUBL, Bosnia and Herzegovina, darkopasal@gmail.com \\ ${ }^{*}$ Corresponding author
}

\begin{abstract}
The subject of research of this work is migration from $\mathrm{BiH}$ from the end of the $20^{\text {th }}$ century until today. The aim of the study is to analyze the consequences of total migration and other demographic losses in $\mathrm{BiH}$, that have reached the highest percent of migration during the nineties of the $20^{\text {th }}$ century in Europe after the Second World War. The results of the research show that migration demographic losses were approximately $25 \%$ of nowadays population number in $\mathrm{BiH}$. The long-term effects of emigration came to the fore. By emigration of the most vital age groups has led to the reduction of fertile cohorts, which results in a decrease in birth, increase in mortality rates and population aging. In the first decade of this century, there was a negative birth rate. Several factors have had influence to the biological (natural) depopulation and the first one was emigration. Continuous and intense emigration was one of the main cause why $\mathrm{BiH}$ was in the group of European countries with expressed population aging. After the $20^{\text {th }}$ century where population of $\mathrm{BiH}$ was doubled, $21^{\text {st }}$ century was marked by the total depopulation. Among various factors that have an influence to the demographic perspective of $\mathrm{BiH}$, the most important is negative migration balance. The social impact of migration in $\mathrm{BiH}$ is visible and multidimensional. War and post-war changes have led to the sensibility of many groups to economical and political turmoil that resulted in lag in the overall development.
\end{abstract}

Keywords: migration, demographic losses, emigration, depopulation

\section{INTRODUCTION}

Migrations, by content and methodology are considered as the most comprehensive variable of population movements. Therefore, unfortunately, methodological solutions are rare in this area with the aim to contribute to the understanding of migratory movements. The most important reason of insufficient migration research lies in the fact that in many statistics there is no quality empirical data on migration, which makes it difficult to calculate the corresponding indicators.

The general picture of the migratory movements can be obtained by using absolute and relative data for a longer period. Since the absolute numbers of immigrants, emigrants and mechanical increase in direct relation to the number of inhabitants in the comparative analysis to show changes in migration in a certain period, using relative indicators, ie. ratios or rates. The most commonly used are net migration rates and gross migration rates. 
The population structure is a key for demographic determinants of migration, therefore, more detailed and more comprehensive analysis of migration flows that are the subject of this paper, includes other specific indicators and more complex methods.

According to relevant demographic and statistical indicators, population of $\mathrm{BiH}$ is marked by reduced fertility, a negative natural population growth (natural depopulation), immigration depopulation, depopulation and the aging of the population. Such population frame of $\mathrm{BiH}$ is an effect of demographic movements and social events through the ages, but the main contribution in its figuration was in the 20th century, with a pronounced acceleration to the present day. That was the period fraught with social, political, military and economic developments and crucial changes. General factors are in this whirl, but also many special ones, that connectively affects and differently contributes to the creation of complex images of demographic reality. One of these general factors, which also has a special " local " meaning, are external migration and emigration, as well as the output variable of that process and the negative side of the overall demographic balance.

The question is: why do people move? Or why some of them move, while others do not? Part of the answer undoubtedly stems from the uneven socio-economic development and its temporal and spatial dimensions. It has been proven in numerous studies that the economic factors are an important determinant of population migration between the two regions. Of course, this does not disregard other factors (which are sometimes predominant): natural-geographical, social, cultural, political and other. Because the migration process is a kind of innovation, there is no doubt that the disposal of information of the 'outside world' precondition (presupposition) of migration. The availability of transport means and traffic technical revolution resulted in the increase in earnings and a preference for seeking a better life abroad. The role of information and availability of transport means in the observed process suggests that emigration is not always the greatest in the poorest (peripheral) areas, as is commonly thought. In the early stages of emigration, people who are a bit wealthier, more capable and more willing to take a risk, leave (Nejasmic, 1991). Who will migrate, largely depends on motives, preferences and capabilities of the individual or group, therefore the individual determinants. It should be noted that all parts of a certain country usually do not participate equally in the 'export' of the population. In areas, which took place intensively, emigration has left the more difficult side effects of demographic and other consequences.

As an integral part of the overall population trends, migration act: a) to the size of the total population and its spatial distribution, b) the natural movement (birth and death) and c) the composition of the population (demographic, socio-economic and cultural-anthropological) (Nejašmić 2005). In addition, it should be noted that emigration has two-time effect: a) current, which immediately reduces the number of inhabitants, and b) long-term (delayed), arising from the current, and it is reflected in the fact that the population who leaves their native place, at the same time ' takes away" their future births, deaths, marriages and divorces that would be experience in their lifetime if they hadn't move from their native place. Therefore, induced reduction by emigration in fertile cohort brings the reduction in birth rate of migrant native place, but also brings an increase in mortality rates since mostly younger part of the population is moving, who are also less susceptible to the risk of death. The result is the reduction of population growth, which ultimately may lead to the natural depopulation. However, it must be pointed out that in the early phase, emigration may have the short-term beneficial effect that appears as a 'demographic regulator' 'with a slight effect. In the Old World, and agrarian rural societies it reduces population pressure "(Woods 1982: 131).

It is generally known that the migration from the general social and ethnic standpoint of population for each country has the special importance. In this paper, we consider the case of $\mathrm{BiH}$ in the period from 1948 2013, starting from its present territorial coverage. The focus is on the cognition of importance of semicentennial emigration (dynamics, trends, extent) and its impact on the main demographic changes in $\mathrm{BiH}$. The purpose of this paper is to make a modest contribution to the general knowledge of population processes, and above all the contribution to the knowledge of the demographic development of the national area.

\section{THE METHODOLOGICAL FRAMEWORK RESEARCH}

In the study of demographic change in the decades-long period in $\mathrm{BiH}$ there are several methodological difficulties. It is hard to answer the question about the number of displaced people in such a long period. In many countries, researchers have difficulties with statistic material on migrations. In Bosnia and Herzegovina it is particularly prevalent. The main reason is the absence of any data. External migrations are mainly the weakest followed part of demographic statistics around the world, although this form of spatial mobility is a great interest of the profession and politics. 
It is obvious that there is a discrepancy between the interests and opportunities. In the absence of accurate data necessary for determining the balance of migration flows, the migration balance is being calculated. This was done in this paper. It is about comparative or vital-statistics method of migration research based on the total number of inhabitants and natural change between the two censuses. Migration balance (B) form is obtained from:

$B=P 2-(P 1+P p)$,

$\mathrm{P} 2$ is population of a given area at the end of the period, $\mathrm{P} 1$ is population at the beginning of the period, and $\mathrm{Pp}$ is natural change (the difference between the number of live births and deaths) in this period. So, the data of the census and demographic (vital) statistics is used. The difference is gained between the actual enumerated population (P2) and (expected) population that would be listed if the population between the two censuses was numerically growing (or shrinking) only on the basis of natural changes $(P 1+P p)$. The result means the difference between the number of immigrants and emigrants. The positive balance shows how many people immigrated more than those who emigrated, and negative balance shows how many more emigrated than immigrated.

One of the difficulties in the demographic analysis is the comparison / incomparability of the total population. From 1971, since the officially recognition of numerous labor and temporary emigration abroad, with a enumerated population in the country (in the place of residence) everyone is included into total population who could be enumerated abroad, or for who relatives could confirm that they are residing abroad. The methodology of the census in 2013 differs from the previous census methodology. In that census, the concept of 'habitual residence' '(place of usual residence) with a time limit of absence to twelve months (according to recommendations of EEC / EUROSTAT and UNSTAT-a) has been accepted. Some determinants of conception deiure have remained in the final, eg. a contingent of citizens abroad who maintain closer ties with their homeland (ie. They return in the place of permanent residence seasonally and monthly). The part of $\mathrm{BiH}$ citizens who are working or staying abroad for more than twelve months were included in census. That means that recommendations were not consistently implemented, and the coverage of this contingent was the subject of subjective evaluations (criteria were not clearly defined). The differences in methodology "administrative" affect particularly the comparability of census data of 1991 and 2013.

\section{RESEARCH RESULTS}

\subsection{The Migration Losses In The Period Of 1948 To 1991}

The century's emigration character of Bosnia and Herzegovina is particularly prominent in the decades after World War II. It was the region of Yugoslavia, along with Montenegro and Macedonia, which was in all postwar censuses awarded with a negative migration balance, ie. more emigrants than immigrants. At the same time, the continuing trend of strengthening emigration components from Bosnia and Herzegovina is evident.

Emigration from $\mathrm{BiH}$ since the first post-war census in 1948 until the census in 1991 and the breakup of Yugoslavia has been marked by three major streams: a) permanent emigration (1948 - 1961), b) moving out after the opening of the borders (going to work) (1961 - in 1991.) and c) emigration to other Yugoslavian republics (1948 - 1991).

Wave of migrations on a large scale has started in 1968. Non-agricultural economic sectors were unable to absorb the entire labor force that came from the countryside, while unemployment continued to grow. Besides the five-year development plan of the country (1966 - 1970) has envisaged a slowdown of employment rate (Wertheimer- Baletić, 1969). Undoubtedly, the additional increase in unemployment caused serious social crisis. Therefore, salvation exit has been found in the " opening of the borders " and allowing residents to be employed abroad. An appealing factor has contributed to the mass departure, which is quite understandable - the demand for all profiles of workers, the possibility of multiple higher earnings, favorable conditions for professional work in the field and so on. Thus, the Western European market attracted not only deagrarated population and unemployed, but also a large number of employees, there were such workers abroad among others about 35.5\% in 1971. " The Promised Land" becomes Federal Republic of Germany, where about $70 \%$ of $\mathrm{BiH}$ migrant workers of total contingent worked in 1971.

It was already mentioned that the census of 1971 includes citizens working abroad, and since 1981 their family members who reside with them. Census is not the best source for monitoring the external migration, they give the current status (current overview of the situation), and that so every ten years. Censuses in terms of the number of citizens abroad are unreliable because it is estimated that in the overseas only a small part of an emigrated contingent was included.

In the period after the Second World War, Bosnia and Herzegovina was characterized by strong emigration, 
the most prominent among the areas of the former Yugoslavia. The reasons for this should be sought in the economic and demographic factors. Disparate impact of these factors in $\mathrm{BiH}$ and in the Yugoslavian area has created conditions for maintaining constant negative migration balance as a whole throughout the aforementioned period. Economic and demographic circumstances in $\mathrm{BiH}$ have encouraged people to emigrate.

Table 1. Net migration balance in BiH 1948-1990.

\begin{tabular}{|c|c|c|}
\hline Period & $\begin{array}{c}\text { Net migration balance } \\
\text { Total }\end{array}$ & Annual \\
\hline $1948-1952$. & -29.779 & -5.956 \\
\hline $1953-1960$. & -161.610 & -20.201 \\
\hline $1961-1970$. & -216.072 & -21.607 \\
\hline $1971-1980$. & -133.780 & -13.378 \\
\hline $1981-1990$. & -171.207 & -17.121 \\
\hline
\end{tabular}

Source: Calculated by vital-statistical method

In the period from 1948-1981., 548,417 people had emigrated from $\mathrm{BiH}$, and 158,291 immigrated in it. The percentage of net migration balance of the population is different in certain periods. The smallest was in the interval from 1948 to 1952 , when the average population was $1.1 \%$, and the highest $6.1 \%$ in the period 1961-1970. However, the percentage of net migration balance in relation to the population growth rate is far higher and the ninth decade exceed up to $40 \%$. Therefore, emigrations from $\mathrm{BiH}$ have been very significant.

The economic impact of the huge migration balance is coming from the fact that $\mathrm{BiH}$ was less developed than the immigration area of the former Yugoslavia. On the other hand, the demographic processes in $\mathrm{BiH}$ were more dynamic than in the former Yugoslavia as a whole, so that it exerted constant pressure to move to regions where the demographic dynamism is weaker.

In the beginning, the migration of workers took place after the model of temporary, circulating workers, ie. the model of gastarbeiter ("guest workers", the term originated in the Federal Republic of Germany). It has been calculated that during conjuncture migrants will insure the necessary workforce (without some major social and union rights) and with the beginning of crisis they will be returning home. An opinion that this model not only suits hosts but also the migrants themselves and the countries of origin (Bade, 1997) has been spread. Yet, over time, the conversion of temporary migrant workers into permanent migrant workers has strengthened, abroad worker becomes an emigrant.

It was already highlighted that the post-war migrations from the former Yugoslav republics were considered in the context of external migration. This was done for the period from 1948 - 1991. According to relevant sources it can be determined that in that period approximately 350,000 people emigrated from $\mathrm{BiH}$ to other Yugoslav republics (now independent states) (Breznik, 1975).

Bosnia and Herzegovina is in the second place according the external migration (after Croatia) because 4.7\% live outside its territory (205.720). Biologically, the most reproductive part of the population was leaving $\mathrm{BiH}$. A special problem is the mass phenomenon of emigration of highly qualified workers, qualified workforce and highly educated young people.

\subsection{Migration Losses in The Period 1991 - 2013.}

In the early nineties, $\mathrm{BiH}$ had one of the special stages of its socio-political and demographic development. The war on its territory and the post-war and transitional difficulties, with an inevitable impact on social events and processes, in particular shook the demographic trends. The war in Bosnia in the early nineties caused a very intense emigration. Migration losses as a result of the war (1992-1995.) were amounted to 527,000 people. On the basis of the number of immigrants in the inter-census period $1991-2013$, vital statistics, and the application of methods for determining the statistics of vital migration, we can estimate that from 1991 to 2013 , around 860,000 people emigrated, which is $11.5 \%$ of the average population. That migratory current was mainly caused by the war (refugees), but economic opportunities as well. 
The highest average annual negative rate of net migration was recorded in Bosnia and Herzegovina in the period 1992-95 (-51.8 per 1,000 inhabitants), with a total loss of one million people. Half of that loss was recovered between 1995 and 2000 (close to 500,000, and the rest is out of $\mathrm{BiH} 527,000$ ).

Table 2. Demographic losses in $\mathrm{BiH}$ (1991-2013).

\begin{tabular}{|c|c|c|}
\hline $\begin{array}{c}\text { Category of } \\
\text { demographic losses }\end{array}$ & Absolutely & $\%$ \\
\hline $\begin{array}{l}\text { Direct demographic losses } \\
\text { (war mortality) }\end{array}$ & $110.000^{2}$ & 9,5 \\
\hline $\begin{array}{c}\text { Migration losses } \\
\text { (as a result of the war) }\end{array}$ & 908.480 & 78,4 \\
\hline $\begin{array}{c}\text { Total real demographic } \\
\text { losses }\end{array}$ & 1.018 .450 & 87,9 \\
\hline $\begin{array}{l}\text { Net demographic losses } \\
\text { (losses of birth rate) }\end{array}$ & 140.000 & 12,1 \\
\hline $\begin{array}{c}\text { The total demographic } \\
\text { losses }\end{array}$ & 1.158 .450 & 100,0 \\
\hline
\end{tabular}

Source: Pašalić, S. (2012). Expert report, ICTY, Hag

Taking into account (decrease) of population in Bosnia and Herzegovina between 1991 and 2013, it is possible to quantify their impact on the resulting reduction of the total population in that time horizon (which was, as stated, amounted to 845,874 , or $1,041,874$ ), and that:

$\mathrm{D}=(\mathrm{N}-\mathrm{M})+(\mathrm{I}-\mathrm{E})=\mathrm{D}(665.505-688.900)+(-908,480)=(-23,395)+(-935,085)=-958480, \quad$ total number of population from 2013 was derived in the form:

$\mathrm{D}=\mathrm{P} 2$ - $\mathrm{P} 1$ which leads to the Inter-census change:

$\mathrm{P} 1=4,377,033$ (1991) - 958,480 (total demographic losses in 1991/2013.) = 3,481,553. From this number, the listed non-residents are subtracted $(196,000)$, which brings us to the total number of permanent (resident) population of $3,285,553$. It is necessary to add 49,606 immigrants (immigrants in $\mathrm{BiH}$ )to this number, which ultimately gives 3335159 (P2). This number is almost the same as the team announced the IMO (a variant of $3,356,073$ ) and P2 $-\mathrm{P} 1=3335159$ to $4377033=-1041874$.

So during census period, between 1991 and 2013, the negative migration balance was the main factor in the general depopulation in $\mathrm{BiH}$, while the natural reduction affected in the same direction, but with a much lower rate. We should therefore emphasize that this is, above all, the war worsening migration balance, which was already negative before.

Table 3. Preliminary results of the census of $\mathrm{BiH} 2013$.

\begin{tabular}{|c|c|c|c|c|}
\hline $\mathrm{BiH}$ & Serbs & Bosnians & Croats & Others \\
\hline 3.791 .622 & 1.155 .531 & 1.903 .721 & 593.902 & 138.468 \\
\hline $100 \%$ & 30,5 & 50,2 & 15,7 & 3,6 \\
\hline
\end{tabular}

Source :Preliminary results of the census of $\mathrm{BiH}$ 2013., BiH Agency for Statistics, Sarajevo

\footnotetext{
${ }^{2}$ Into total mortality rate are included: died by natural death $(578,900)$ and died in the war (war mortality 110.00)
} 
In the census of 2013 a new concept was applied to, ie. the concept of the present (de facto) of the total population, but something changed in relation to its original meaning. In accordance with the recommendations of the UN Economic Commission for Europe and the Statistical Office of the European Communities Act from 1998, the definition of the total population in the census of 2013, based on the principle of " habitual residence '(usual residence), which, however, is not completely identical to the standard definition of that term. Namely, it is essential that the total population of $\mathrm{BiH}$ do not include its citizens who are abroad for more than a year and, at the same time, include foreign citizens who reside in $\mathrm{BiH}$ for more than a year. Thus, it appears that 2013 census data on the total population and population in certain structures are not precisely comparable with the same data from previous censuses.

Table 4. Results of census in $\mathrm{BiH} 2013 .{ }^{3}$

\begin{tabular}{|c|c|c|c|c|}
\hline BiH & Serbs $\%$ & Bosniaks $\%$ & Croats $\%$ & $\begin{array}{c}\text { Others } \\
\%\end{array}$ \\
\hline 3.531 .159 & 1.086 .733 & 1.769 .592 & 544.780 & 130.036 \\
\hline $100 \%$ & 30,78 & 50,11 & 15,43 & 3,68 \\
\hline Demographic losses .91/13 & -279.371 & -133.364 & -216.072 & -217.085 \\
-845.874 & $-20,45 \%$ & $-7,00 \%$ & $-28,40$ & 62,53 \\
$-19,32 \%$ & -68.798 & -134.129 & -49.122 & -8.432 \\
\hline Dem.losses/preliminary/final & $-5,95 \%$ & $-7,04 \%$ & $-8,27 \%$ & $-6,09 \%$ \\
\hline
\end{tabular}

Data source: BiH Agency for Statistics, the final results, 30.6.2016

If we elaborate further reduction in the total population of $\mathrm{BiH}$, in the censuses between 1991 and 2013, analytically, from demographic statistical point of view, it is shown that this reduction was caused by the two components of total depopulation: natural reduction of population (including war mortality) and negative net migration. We concluded that the decrease in the total number of population in the period from 1991 to 2013 was formed under the influence of both its determinants, natural decline and a negative migration balance.

But if we take into account the census results published by the Agency for Statistics of $\mathrm{BiH}$, where the permanent (total) population and listed people who live longer than a year outside the country were included, and then exclude them from the permanent (total) number, we will get more objective and real (current) state of total population in $\mathrm{BiH}$ and its lower territorial units.

Census 2013 has shown that the current trend is further deteriorated by the uneven spatial distribution of the population. Such deployment, according to rule is the result of uneven economic development, but also economically more backward areas are areas of poor natural demographic dynamics and simultaneously intense emigration. Today, however, such demographic characteristics of certain areas have become a factor (cause) of their economic backwardness because without their demographic revitalization there is no basis for further socio-economic development.

3 The results of the list published by the Agency for Statistics of $\mathrm{BiH}$ without the consent of Republic Institute for Statistics of the Republic of Srpska 
Table 5. Population in BiH without non-residents (census 2013.).

\begin{tabular}{|c|c|c|c|}
\hline BiH & $\begin{array}{c}\text { Republic } \\
\text { of Srpska }\end{array}$ & $\begin{array}{c}\text { Federation of } \\
\mathrm{BiH}\end{array}$ & $\begin{array}{c}\text { Brcko } \\
\text { District }\end{array}$ \\
\hline 3.335 .159 & 1.178 .668 & 2.078 .239 & 78.252 \\
\hline $100 \%$ & 35,34 & 62,31 & 2,35 \\
\hline $\begin{array}{c}\text { Demog.losses } \\
\text { prelim./final }\end{array}$ & -148.323 & -293.364 & -14.776 \\
\hline
\end{tabular}

Source: Appropriate processing based on primary data sources

In the previous post-war period, immigration to Bosnia and Herzegovina is directed primarily owards and around Sarajevo (Canton Sarajevo) from the interior of Bosnia and Herzegovina, and from, so called, arabic countries.

The refugee exodus from Bosnia and Herzegovina to Serbia and Croatia was much higher. Between 1991 and 1997, according to official data, Croatia is populated by about 240,000 people from Bosnia and Herzegovina. But part of it is moved further towards the Western European and overseas countries, and some of them stayed and took Croatian citizenship. (Markotić 1999: 751-754). Number of displaced into Serbia was ranged up to 260,000 , which was confirmed by the census of 2002 , that had given a number of more than 400,000 people in Serbia ,who have moved from the 90's of the last century from the former Yugoslav republics.

\subsection{Demographic Aging}

The results of the analysis have confirmed the allegation in the introduction that $\mathrm{BiH}$ is part of countries that have had a significant loss of population in migration flows. Particularly, the exodus is distressing (migration losses) in recent decades as it has been placed in circumstances of reduced fertility, negative birth rate, depopulation and the aging of the population.

Census 2013 has highlighted the major demographic disturbances in $\mathrm{BiH}$. The most important of all are: depopulation, dwindling villages, aging, exile, emigration abroad, etc. These changes limit the overall socioeconomic development. It is now clear that human resources are not unlimited and that any consideration of the future must take into account the minimum population needed to maintain existing infrastructure. Emigration of young people creates, so-called, derogated generations in the age structure (numerically weak), and, as already mentioned, it forms a long-term (delayed) effect due to the outflow of (bio) reproductive potential. Thus, derogated generation of parents affects the emigration areas to reduce the number birth rate, which, by the action of other factors, results in the aging of the population, which leads to increase in the proportion of people in older age (60 and over or 65 and over). So changes in the age composition of the population in Bosnia and Herzegovina contain two parallel global demographic processes: reducing the share of young people and at the same time increasing the share of the older population. The population aged over 65 is considered old. 
Table 6. Age structure of BiH population (1991. and 2013.).

\begin{tabular}{|c|c|c|c|c|}
\hline \multirow{2}{*}{ The age } & \multicolumn{2}{|c|}{$1991 . y e a r$} & \multicolumn{2}{c|}{ 2013.year } \\
\hline & Population & $\%$ & Population & $\%$ \\
\hline $0-14$ & 1.027 .391 & 23,5 & 543.719 & 15,4 \\
\hline $15-64$ & 2.962 .815 & 67,7 & 2.485 .444 & 70,4 \\
\hline $65+$ & 284.365 & 6,5 & 501.996 & 14,2 \\
\hline Unknown & 102.462 & 2,3 & - & - \\
\hline Total & 4.377 .033 & 100 & 3.531 .159 & 100 \\
\hline
\end{tabular}

Source: Statistical Yearbook 1993-1998. Federal office of Statistics, Sarajevo, 1998.

Census in BiH 2013., Statistics Agency of BiH, Sarajevo, 2016.

Beside increasing the proportion of old ones in the total population (old people $14.2 \%$ ) it was recorded also a significant reduction in the proportion of people aged $0-14$ (from $23.5 \%$ to $15.4 \%$ ), which is also a relevant indicator of demographic aging. The aging process is gaining unfavorable characteristics with every census. Comparison of the data of the 1991 census and 2013 census shows that the population of $\mathrm{BiH}$ is marked by rapidly aging and a high degree of aging. The change in 1991 - 2013 shows a decrease in the number of young (under 34 years), with a particularly strong reduction of the youngest groups, on the other hand an increase in the number of an old population, particularly the oldest age groups (partial aging).

Table 7. Functional age indicators of $\mathrm{BiH}$ population 4 .

\begin{tabular}{|c|c|c|c|c|c|}
\hline Territory & Age type & $\mathbf{k}_{\mathbf{m}}$ & $\mathbf{k}_{\mathbf{s}}$ & $\mathbf{i}_{\mathbf{s}}$ & $\mathbf{I}_{\mathbf{o}}$ \\
\hline Bosnia and Herzegovina & profound & 15,39 & 14,21 & 0,92 & 46,14 \\
\hline Republic of Srpska & profound & 14,14 & 16,59 & 1,17 & 41,07 \\
\hline Federation of $\mathrm{BiH}$ & profound & 16,08 & 12,88 & 0,80 & 49,91 \\
\hline Brcko District & profound & 15,86 & 14,53 & 0,93 & 33,09 \\
\hline
\end{tabular}

Source: Appropriate processing based on census data of $\mathrm{BiH} 2013$.

The high increase in the share of an old population, especially the oldest part of that contingent, shows that $\mathrm{BiH}$ is closer to the situation in developed European countries, where (at least most of them) much more rapidly grows share of people in the older age group of an elderly contingent (Nejašmić, 2003). And other analytic indicators of composition according to age confirm represented results. The average life expectancy (age) of the $\mathrm{BiH}$ population is constantly growing. In the year 1991 it was 34 years, 39.5 years in 2013. Index of age (the number aged over 65 years to 100 young people 0-14) in 1991 was 54.4; in 2013 it was 91, $9^{\text {th }}$. In order to understand the process of aging, it is very vivid comparison of child base $(0-4)$ and people aged over 75, 2013 so the age groups were practically equal. An inversion of age pyramid is getting more significant in the act.

${ }^{4}$ The data are calculated without excluding the 196,000 non-residents of the total population, which in certain percentages changes determined coefficients and indices, especially in the Republic of Srpska, where the larger number of non-residents from the category of the older population was enumerated. As distinct from, in the Federation of $\mathrm{BiH}$ mostly younger contingent of the population was enumerated, which in certain percentages gives favorable depiction of those coefficients and indexes. 
Judging by the presented analytical indicators, the population of Bosnia and Herzegovina is marked by profound age.

\section{CONCLUSION}

In the period, from 1948 - 2013, strong emigration from the territory of present-day Bosnia and Herzegovina constantly takes place, around 1.3 milion inhabitants have emigrated. With the time, the migration has not weakened, and still going strong, which is of particular importance from the standpoint of the demographic consequences, because it occurs in case of low birth rate, depopulation and the aging of the population. Emigration at the beginning of the 20th century had occurred in the circumstances of a very high birth rate, thereby partially, an outflow of human capital was alleviated. However, the immigration contributed to it quite a lot, which compensated half of total emigrated contingent. In fact, immigration has delayed $\mathrm{BiH}$ "demographic collapse" for half a century. The loss arised from historical external migration has absorbed $33.4 \%$ of the average population, or $52 \%$ of total natural change (population growth). Few countries have had such population loss in the external migration.

Emigration or negative migration balance is the main factor (stronger than war losses and epidemics) of demographic losses and slow population growth in $\mathrm{BiH}$ in the 21 st century. In the hypothetical 'reserved population' (i.e. without external migrations) $\mathrm{BiH}$ in 2013 had at least 4.5 million people or $30 \%$ more than the registered number. External migrations with spatial selectivity of their incoming and outgoing flows also affected the differentiated regional demographic development of $\mathrm{BiH}$.

Long-term (delayed) effects of emigration are fully emphasized. Emigration of the most vital age groups has led to the narrowing of fertile cohort, and consequently to the decrease in birth and increase in mortality rates. Several factors have affected the biological (natural) depopulation, but in the first place is continuous and strong emigration. This is one of the main factors why $\mathrm{BiH}$ had an accelerated process of demographic transition. The emigration of young age groups (and the potential parents) has also with depopulation an important contribution in the aging population, a dominant demographic process in $\mathrm{BiH}$.

Thus, it can be concluded that the continuing circulus viciosus emigration (negative migration balance), more pronounced inversion of age pyramid and ultimately unfavorable changes in terms of natural movement. By the legality of demographic inertia, and that negative momentum, it will affect the further deterioration of the age composition (aging) and reduction of the total population of $\mathrm{BiH}$.

\section{REFERENCE LIST}

Ben-Daya, M., Darwis, M. and Ertogral, K. (2008). The joint economic lot sizing problem: Review and extensions. European Journal of Operational Research, vol. 185.

Breznik, D. (1975). Unutrasnje migracije. Jugoslovenski pregled, 19 (5).

Hranilovic, N. (1987). Iseljenicka politika i sluzba u Jugoslaviji između dva rata. Migracijske teme, 3 (3-4).

Jones, H. (1990). Population Geography. Paul Chapman.

Nejasmic, I. (2005). Demogeografija: stanovnistvo u prostornim odnosima i procesima. Školska knjiga.

Nejasmic, I. (2008). Stanovnistvo Hrvatske: demogeografske studije i analize. Hrvatsko geografsko drustvo.

Pasalic, S. (2002). Antropogeografska stvarnost Srba u BiH 1992-2000. Banjaluka Kompani.

Pasalic, S. i sar. (2006). Demografski razvoj i populaciona politika Republike Srpake. IP Mladost.

Pasalic, S. (2012). Demografski gubici u BiH 1991-2011.Vlada Republike Srpske, Ministarstvo pravde.

Pasalic, S.(2013). Export report. ICTY.

Pasalic, S. (2014). Demografska buducnost Republike Srpske - izumiranje stanovnistva ili populaciona revitalizacija. Zbornik radova Opstanak. Ur.Dragan Batavelic. Aleksandrovac.

Wertheimer-Baletic, A. (1999). Stanovnistvo i razvoj. Mate.

Zerjavic, V. (1989). Gubici stanovnstva Jugoslavije u drugom svjetskom ratu. Jugoslavensko viktimolosko društvo. 